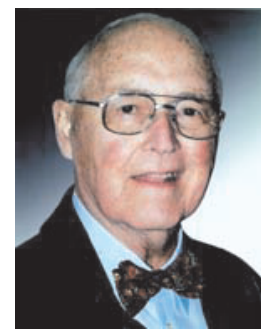

\title{
Robert Anthony MacMahon
}

ROBERT MACMAHON AM, MB BS, MS, FRCS, although publicly renowned as a paediatric surgeon, was far more teacher, innovator, a family man with a delightful sense of humour, and founding governor of the Make-A-Wish Foundation

Bob was born in the Sydney suburb of Eastwood on 22 April 1931. He studied medicine at the University of Sydney, graduating in 1954. He undertook 4 years of training at the Royal Newcastle Hospital, and spent his spare time in the surf and on the rugby field for the Newcastle Wanderers. He then studied in the United Kingdom, where he decided to become a paediatric surgeon.

After obtaining a Master of Science from the University of Colorado Denver, he returned to Sydney in 1965, to become the first James Fairfax Surgical Research Fellow at the Children's Medical Research Foundation.

In 1967, he was appointed inaugural Head of the Department of Paediatric Surgery at the Queen Victoria Medical Centre (later Monash Medical Centre), Melbourne. In 1970, he became Associate Professor of Paediatric Surgery at Monash University.

At Monash, he developed his interest in the nutrition of premature infants, running a research program in amino acid and mineral metabolism. Between 1970 and 1975, through intravenous feeding, he increased premature infant survival from $18 \%$ to $71 \%$.

In 1974, Bob founded the Australasian Society for Parenteral and Enteral Nutrition and was its inaugural President. He served on the Monash University Human Research Ethics Committee for 40 years, and was its Chair from 1999 to 2009. He was President of the Australian and New Zealand Association of Paediatric Surgeons from 1991 to 1993.

He performed the first human fetal operation in Australia and the first in-utero repair of a diaphragmatic hernia. He also pioneered in-utero laser vesicostomy and helped create the Fetal Diagnostic Unit at Monash Medical Centre.

Throughout his career, Bob contributed to 10 textbooks and authored more than 60 research articles.

In 2010, he was made a Member of the Order of Australia. After he retired from medicine, he enjoyed camping in the bush, surfing and golf.

Bob died on 1 April 2011 from prostate cancer, and is survived by his wife Bessie and four daughters. He will be remembered for his personal integrity, enthusiasm, achievements, intellect and judgement, and his wonderful sense of humour.

Robert J Stunden doi: 10.5694/mjall.10876 